\title{
ACERCA DE "FILOSOFIA CLÍNICA"
}

Marcelo L. Pelizzoli*

SÍNTESE - A questão central que se nos coloca é da utilização da Filosofia na prática clínica (psicoterapêutica e de aconselhamento). É uma reflexão acadêmica crítica dirigida exclusivamente ao debate da temática, diante de tentativa de alguns estudantes e professores de filosofia no Rio Grande do Sul de autorizarem-se a tal prática como "filósofos clínicos".

PALAVRAS-CHAVE - Filosofia, clinica, psicanálise, psicologia, profissão.
ABSTRACT - The main question which we have been facing is the use of Philosophy in practical (psychotherapeutic and advisory) clinical treatment. It is a critical academic consideration directed exclusively to the discussion of such topical subject, related to the attempt of some Philosophy students, teachers and professors in Rio Grande do Sul to be allowed to apply it as "Clinical Philosophy".

KEY WORDS - Philosophy, clinics, psychoanalysis, psychology, profession.

\section{Contexto da questão}

Hoje, como nunca, com a virada lingüística e as análises da comunicação, conjugadas aos estudos psicológicos sérios, é-nos possivel, principalmente a nós, "filósofos", não nos deixarmos enredar pelo fascinio que sempre exerceram uma gama de significantes (palavras e redes conceituais, de cunho psicologizantes) do discurso das Ciências Humanas. É certo que os discursos que se valem das "entrelinhas", do oculto, do inconsciente, do Si mesmo, ou da trama de certas redes conceituais confusas que almejam preencher a lacuna interior do humano (Desejo) com algum Eldorado (compleção), sempre exerceram influências numinosas nas nossas mentes pouco afeitas ao mundo do imaginário, da introversão, do simbólico e do inconsciente. Entrementes, a Psicologia e a Psicanálise, praticamente, já se incorporaram à cultura ocidental, permeando pois o discurso acadêmico, os meios mais intelectualizados e o próprio senso comum. Isto não implica que o senso comum tenha uma consciência plausível do que se trata, nem a academia por vezes. Outra coisa é a prática clínica, a profissão de psicoterapeuta e todo o trabalho institucional, acadêmico, científico e envolvimento experiencial que isto exige.

A questão é que, com o incipiente trânsito e cabedal teórico, cultural e científico de nosso país, somados à pulverização do sentido e dos valores e instituições

" Doutorando em Filosofia da PUCRS. Livre pesquisador em Psicanálise.

\begin{tabular}{|l|l|l|l|l|l} 
VERITAS & Porto Alegre & v. 43 & $\mathrm{n}^{2} 1$ & Março 1998 & p. 181-183
\end{tabular}


de nosso tempo, percebemos uma recorrência incauta, despreparada, fascinada e sem base a uma gama de "teorias", de práticas, de "atalhos" que costumam ser altamente periculosos, principalmente para quem está na "outra ponta". De uma outra forma, isto pode ser visto também no pipocar das novas seitas religiosas. Estamos ávidos por respostas, por autoconhecimento, por saídas. Não será necessário então recorrermos a instrumentos eficazes de proteção ao "consumidor"?

Não podemos desconsiderar a verdade (veja-se C. G. Jung) de que as psicologias são um sintoma claro de nossa época, quando vêm como demanda de autoconhecimento de um ser humano cada vez mais à procura de si mesmo e do $\mathrm{Ou}$ tro; que quer penetrar os segredos de sua gênese e história, a história de sua subjetividade consciente, o que há de mais misterioso na evolução da natureza. Eis que nossa época é cada vez mais eivada de práticas e buscas psicológicas e "filosóficas" das mais diversas e multifacetadas, que reúnem num mosaico, por vezes pouco sustentável e simplória, uma infinidade de pequenos recortes, "numinosos", atraentes, que se unem para formar uma possivel alternativa. É até normal, é sintoma de nosso tempo em crise (ruptura...), em mutação. Observamos, não obstante, que as grandes correntes, psicoterapêuticas, psicanalíticas e psiquiátricas que conhecemos hoje, não se fizeram sem grandes aportes teóricos, experimentados numa longa prática, não raro por cabeças realmente geniais, que tinham claro aquilo que propunham e aquilo a que se propunham. Há então, acima de tudo, a exposição das teses ao debate público, bem representado no meio acadêmico e científico, ou seja, com autoridade e por autoridades.

Há, pois, uma História da Psicologia e um histórico a que podemos recorrer e aprender bastante. Vemos então que isto não é algo que se produz ávida e impensadamente; não é algo que foge ao crivo judicativo de uma Tradição, mas antes, posiciona-se frente a ela, mesmo para ir além dela. Assim, diante das novidades psicoterapêuticas, devemos sempre buscar situá-las desde seu locus e ponto de partida, dentro do histórico terapêutico, rastreando cuidadosamente sua fundamentação. A fundamentação da produção cientifica é uma garantia para a sociedade. Não que devamos barrar as novidades, de modo nenhum! Devemos sim é recorrer a todo o espectro teórico e crítico sólido para não sermos pegos de surpresa e também para não prejudicar as pessoas!

Veja-se que a Psicologia e a Psicanálise sempre se utilizaram do aporte das ciências adjacentes, como a Filosofia (de onde provém histórico-teoricamente), da Lingüística, da Medicina, da Sociologia etc. Contudo, sabem que não podem restar dentro destes recortes, pois estão centradas numa teoria e prática terapêutica definida e aceita, com um corpus e um código ético consistente, com conselhos reguladores etc. $\mathrm{E}$, como tal, formulam aportes clínicos rigorosos mas sempre em discussão. A prática da Psicoterapia - veja-se Freud, Lacan, Jung, etc. - requer uma autoridade que se assenta em práticas clinicas e num corpus teórico terapêutico que qualquer outra disciplina das ciências nunca pôde recobrir, até porque não se propõem absolutamente a tal. Isto não implica contudo que o curso acadêmico de Psicologia seja rigorosamente imprescindivel para a clínica. A Filosofia, a saber, pode ser indicada teoricamente, por exemplo, para a psicanálise lacaniana. Porém, daí para a clínica é um passo árduo, de práticas clínicas intensas do pró- 
prio futuro psicanalista, de grupos de estudos, da supervisão, de seminários, de formação clínica e de formação teórica rigorosa, assentada em patrimônio literário e científico enorme e pertinente. E mais, tal prática é viabilizada em escolas muito bem organizadas e reconhecidas pelo meio acadêmico, institucional e social. Se falarmos em Psicologia, veremos que, sob este registro, encontramos instituições com práticas resguardadas, estatuto legislador que, por mais corporativismo e conservadorismo que possuam, mostraram-se necessários, visto o alastramento de "organismos psi" e também de charlatanismos de nosso tempo.

Atentaria aqui para uma questão cada vez mais urgente em nosso tempo multifacetado: o direito do consumidor, o resguardo e a proteção daquele que recorre aos serviços sociais, de saúde, de aconselhamento, de psicoterapias etc. $\mathrm{Na}$ prática psicoterapêutica, não raro encontramos grandes frustações por parte dos pacientes, visto muitas vezes o aparecimento de "analistas" completamente despreparados. Se não houvesse mecanismos de ação deste gênero, de resguardo do usuário e cliente, como poderíamos nos defender?

Uma "filosofia clínica" demandaria no mínimo um trabalho imenso e longo das melhores cabeças pensantes das Ciências Humanas, que conseguissem, talvez por um passe de mágica, inferir técnicas clínicas de especulações filosóficas, existenciais talvez. Tais cabeças não se propõem a tal, e nós sabemos o porquê. (Obs.: O exemplo de "filosofia prática" e assessoria que se tem na Alemanha nada tem haver com a clínica.)

A Filosofia, sem dúvida, como as outras ciências, atravessa fases de crise e transição grandes; as Ciências não permanecem muito tempo indiferentes às épocas históricas. Temos hoje grandes, urgentes e graves questões, que têm feito a Filosofia aprumar seus instrumentos diante da questão ética, civilizacional, ecológica, globalização político-mercadológica, por exemplo. Ela tem, pois, questões graves a enfrentar, questões epistemológicas dos novos paradigmas, questões dos discursos, do seu próprio estatuto, da fundamentação ética, e questões de profissão. Seu papel também está sendo repensado, num mundo utilitarista e pragmatista. Mas não é por isto que, desde dentro da Filosofia, podemos autorizar-nos a efetivar práticas que não condizem com sua instância. Uma coisa é uma Filosofia da Ciência, ou da Religião, ou Política, outra coisa é partir para uma prática psicológico-terapêutica. Outra coisa também é prestar uma "assessonia filosófica", até humanístico-existencial quem sabe.

\section{Final: questão de ética}

O que está em jogo com tal "filosofia clínica" é antes de mais nada a reputação e o papel da Filosofia frente à sociedade gaúcha e brasileira. Não podemos forjar uma profissão que não tem condições de existir seriamente. É uma questão evidente, e acima de tudo de ética. 